\title{
Actually existing markets: The case of neoliberal Australia
}

\author{
Lynne Chester \\ The John Curtin Institute of Public Policy, Curtin University \\ Email: I.chester@curtin.edu.au
}

\begin{abstract}
The rhetoric and mechanisms of the market have become embedded in public policies with the hegemony of neoliberalism. Markets traditionally supplying public goods have been transformed, a strong exemplar of which is Australia. Using an analytical framework which dissects the structure, operation, interactions and outcomes of real world markets, five Australian markets are analysed to reveal the eligibility rules for access and ongoing participation, interaction of participants, the role of intermediaries and government, the extent of competition, the complex regulatory regimes shaping and controlling these markets, and key market outcomes. Contrary to neoliberalism's free market rhetoric and the view promulgated by mainstream economics, it is found that there is a spectrum of market configurations and governance regimes, participation is highly dependent on technology access and skills, market outcomes are inconsistent with policy rhetoric, market interrelationships pose adverse cumulative impacts, and government is strongly interventionist through a multiplicity of roles.
\end{abstract}

Keywords: Australia, institutions, market structure, mode of régulation, neoliberalism, public goods, public policy

JEL classification codes: B52, D40, H44

\section{$1 \quad$ Introduction}

A vast range of public policies have been restructured around market-based mechanisms based on economic concepts derived from the logic of perfect competitive markets. 'Government by the market', 'market governance', and 'market-based policy' are among the labels applied to this phenomenon and Australia is a strong exemplar. The widespread adoption of market-based policy instruments has meant substantial change to Australian markets which have traditionally supplied public goods such as electricity, water, education, health insurance, public housing, infrastructure, and services for the disabled, aged and unemployed. Most noticeably, direct provision by government of these goods and services has been supplanted and there have been significant pricing changes.

Contemporary Australian public policies are almost exclusively framed in abstract terms of competition, economic efficiency, supply and demand, or the need to address market failures. This is the lexicon of neoclassical economics which portrays the market as a normative ideal framed around a set of abstract assumptions. These assumptions are incompatible with reality and cannot explain the operation and outcomes of these transformed markets for public goods (Chester 2009).

Society of Heterodox Economists, December 2009 
Actually existing - not abstract - Australian contemporary markets are the focus of this paper. How are these markets organised? What ensures their ongoing functioning? What is the nature of the goods and services provided by these markets? How does this differ from previous provision? What issues or barriers do Australians encounter when engaging with these markets? To what extent do these markets ensure adequate provision to those on lower incomes? What outcomes are these markets delivering?

These are the questions which this paper seeks to answer through an analysis of five contemporary real world markets that impact on the daily circumstances and standard of living of the vast majority of Australians - electricity, water, employment services for the unemployed, housing for the low-income and carbon trading. The examples have been deliberately chosen for their breadth of impact across the lives, well-being and social inclusion of the population irrespective of geographical location or stage of the lifecycle. The analysis elucidates the eligibility rules and barriers to market access and on-going participation, the institutions that organise the functioning of these markets, price determination, the interaction between participants and the role of intermediaries, the form of competition in each market, the complexity created by market-based policies, the multiple roles played by government, the key market outcomes, and the similarities and differences between markets.

The paper is structured as follows. Section 2 establishes the broader political economy context in which markets for public goods have been restructured by public policies embodying the rhetoric of neoliberalism and neoclassical economics. The changing institutional architecture of the Australian mode of régulation since the 1980s is discussed along with the form and nature of interventions by the state at both macro and micro levels. The disjuncture between neoliberalism's free market rhetoric and actual outcomes is also explored. The focus of Section 3 is the five contemporary Australian markets for electricity, water, services for the unemployed, housing for low-income Australians, and carbon trading. The section presents the analytical framework utilised, an overview of the development and operation of each market analysed and a detailed comparison of the five markets' structural features, interactions and outcomes. A final section canvasses the implications of the findings, including the disjuncture with the abstraction and assumptions of mainstream neoclassical economics which have imbued Australian public policy.

\section{The case of neoliberal Australia}

\section{$2.1 \quad$ Rhetoric and reality}

Within the observed typologies or varieties of capitalism, Australia is classified as a 'liberal market-based economy', falling in a 'highly homogenous Anglophone cluster' of the US, UK, Canada and New Zealand (Amable 2003; Crouch 2005; Hall and Soskice 2001) given a high reliance on market mechanisms for coordination of the economy. This reliance is evidenced if we consider Australia's mode of régulation which governs, guides, supports and secures the process of accumulation. Five institutional (or structural) forms comprise the mode of régulation, the dimensions of which are defined by: wage-labour's relationship with capital; monetary and credit relationships; the competitive relations between firms; the nature of international relationships and arrangements; and finally, the form of state intervention including economic policy. 
Box 1 presents a generalised synthesis of the contemporary Australian mode of régulation compared to that which prevailed during the previous Keynesian-Fordist golden age. It is apparent from these generalised descriptions that the overall organising principle of each institutional form has become, during the contemporary period, one of market logic heavily directed and supported by strong regulatory interventions by the state. The nature and extent of the Australian state's interventions are far different from those during the period immediately following the Second World War until the 1980s.

\section{Box 1 : Australia's mode of régulation}

$\begin{array}{lll}\text { Institutional } & \begin{array}{l}\text { Keynesian-Fordist } \\ \text { form }\end{array} & \begin{array}{l}\text { Contemporary } \\ \text { characterisation }\end{array}\end{array}$

Wage-labour Centralised wage fixation system, wage nexus growth tied to consumer prices, strong collective organisation of labour and prominent bargaining role, expansion of welfare system and social wage.

Money and New credit forms, housing interest rates finance capped, central bank controls over the banking system, foreign exchange controls.

Competition

Oligopoly and high levels of industry concentration protected by tariffs, legislative focus on anti-competitive behaviour.

International Multi-lateral agreements, growing position internationalisation of financial markets, 'pegged' exchange rate.

Form of the Keynesian welfare state, public state expenditure directed to full employment objective, indirect intervention in markets through wages and price policies.
Heavily regulated decentralised wagebargaining, increasing dominance of individual employment contracts, labour market segmentation into highly-paid skilled jobs and casual/part-time unskilled, lower-wage jobs, increasing private provision of social wage elements, welfare system pared back.

Policy and operational independence of central bank, monetary policy used to fight inflation and scrutiny by financial market, companies run by financial logic, systemic risk exposure of financial markets.

Legislative restriction of concentration, predominance of oligopolistic competition.

Adhesion to free trade principles, increasing global integration through trade, finance and investment promoted by international alliances such as WTO, OECD, APEC and FTAs.

Pursuit of structural competitiveness by proactive and market-enhancing state, fiscal policy pro-cyclical until late 2008, new forms of regulatory intervention using a range of agencies. 
There has been a marked shift in all institutional forms, comprising Australia's mode of régulation, since the 1980s (Chester 2008b). A major influence has been increasing global integration driven by an Australian state which has actively embraced the notions of free trade and the removal of constraints on capital flows through bilateral trading agreements, other international alliances and a raft of economic policy decisions. Competition has been promoted strongly by the state through new national regulatory regimes (the nearly-decade long National Competition Policy and its successor, the National Reform Agenda), new sectorspecific regulation (for example, energy), one of the world's largest privatisation programs, and contracting-out - via competitive tendering - of services previously provided direct by government.

Other significant institutional changes to Australia's mode of régulation, since the early 1980s, have been:

- financial deregulation, the abandonment of monetary targeting, and central bank targeting of inflation;

- the introduction of a consumption tax, cuts in taxation rates favouring capital and taxation concessions increasingly used to 'encourage' individual provision of services such as health insurance and superannuation;

- six Accords with the trade union movement, national wage increases abandoned, centralised wage determination replaced by heavily regulated workplace bargaining, and real expenditure on the social wage reallocated to other functions of government; and

- eleven substantial Federal Budget surpluses in the 12 years ending 2008 with budgetary expenditure following a pro-cyclical pattern, and public debt virtually eliminated until the economic stimulus packages following the recent global financial crisis (ibid).

Although the 'glorification' of markets has been pushed to new extremes, the form of competition remains characterised by monopoly or oligopoly with firms more intent on controlling the market than participating in an ideal pure form. The monetary and financial regime, and particularly the central bank's interest rate policy, is closely scrutinised by international financial markets. Monetary (interest rate) policy has become autonomous of fiscal policy with the exchange rate determined by financial markets.

Moreover, the progressive and cumulative impact of these institutional changes, these interventions by the state, has resulted in a particular configuration of the Australian mode of régulation's institutional architecture. Yet these interventions - by the state at both macro and micro levels - are paradoxical given the prevailing economic and political ideology of neoliberalism that promotes deregulation, much less intervention by the state, and the triumph of 'free' markets. This disjuncture between neoliberalism's free market rhetoric and actual outcomes is immediately apparent from the comparison shown in Box 2.

Neoliberalism's free market rhetoric has pervaded the lexicon of Australian public policy as a vast array of policies have been transformed by market-inspired mechanisms based on economic concepts derived from the logic of perfect competitive markets. Examples include the charging of fees for time spent in immigration detention centres, contracting out of services delivered to the unemployed through competitive tendering, the charging of market rents to public housing tenants, the removal of barriers to free trade such as tariffs and import quotas, the provision of infrastructure through commercial contracts with the private sector, the creation of regulatory agencies to monitor competition, the development of accounting rules to measure greenhouse gas emissions, and student fees set at levels equivalent to the 
costs of providing higher education places. This progressive widespread adoption of marketbased policy instruments has meant substantial change to markets which have traditionally supplied public goods such as electricity, water, education, health insurance, public housing, infrastructure, and services for the disabled, aged and unemployed. Most noticeably direct provision by government of these goods and services has been supplanted and there have been significant pricing changes.

Box 2: Australian free market rhetoric compared to actual outcomes

\begin{tabular}{ll} 
Institutional form & Rhetoric \\
\hline & $\begin{array}{l}\text { Deregulation and flexible labour } \\
\text { markets will ensure full } \\
\text { employment }\end{array}$ \\
\hline
\end{tabular}

\section{Outcome}

Highly-regulated decentralised wage determination system; persistent unemployment and labour under-utilisation

Money and finance

Competition

International position

Form of the state
Interest rates set by market; price stability possible without adverse impact on employment; better service levels and reduced charges with greater competition

Deregulation will increase competition by entry of new firms; greater growth, efficiency and welfare with more competition autonomy of national economic policies
Smooth currency adjustments;

Price stability (inflation target of $2-3 \% \quad$ p.a.) but persistent unemployment and labour under-utilisation; increased range and level of charges; escalating house prices and housing stress

Increasing market concentration in all sectors and oligopolies dominant; increasing regulation of economic activity to make it 'competitive'; infrastructure and utility monopolies continue

Volatile exchange rate movements; national economic policies shaped by needs of TNCs (espec resources sector) and key trading partners (China, India, US)

Minimal intervention will Little public investment in social enhance growth and and economic infrastructure; productivity falling productivity; new forms of social regulation (income management; intervention in indigenous communities); recent stimulus packages reversing budget surplus to deficit equal to $4.5 \% \mathrm{GDP}$

The rationale for these market-based policies has been couched in terms of the need for greater economic efficiency. Consequently contemporary Australian public policies are almost exclusively framed in abstract terms of competition, efficiency, supply and demand, or 
the need to address market failures. More importantly, how are these markets structured and organised to 'deliver' these objectives of competition and efficiency, and address market failure? Is there a disjuncture, similar to that observed with Australia's mode of régulation, between free market rhetoric and the operation, structure and outcomes of real world markets driven by 'free market' imbued policies? To answer these questions an empirical analysis was undertaken, the results of which are presented in the next section.

\section{$3 \quad$ Actually existing markets}

Five markets were analysed, four of which are longstanding markets previously providing goods and services directly and solely by government (electricity, water, housing for lowincome Australians, and services for the unemployed) and the other is a market currently being established (carbon trading). All five markets have, or will have, a widespread impact across the Australian community.

The analytical framework used was that developed by Chester (2009). This framework, or analytical grid, poses a series of questions to explain the structure, operation, participants, behaviours, rules, and price setting which provides a realistic explanation of real world markets. The questions are:

- What is the commodity 'bought and sold'? How are these goods or services defined? To what extent have these definitions changed with the "virtual canonization of market organisation" (Nelson 2005: 1)?

- Who are the market participants (individuals, groups or organisations)? Who transacts with who? Are intermediaries involved?

- What are 'rules' or protocols which determine eligibility or ineligibility for ongoing access to a market? Are there legal and political decisions, or compromises, which determine who participates?

- How does the interaction between 'buyers' and 'sellers' take place? Are particular behaviours forbidden? Are there implicit rules influencing the behaviour of market participants?

- Is there a physical or virtual market location and how is this organised? Is the sphere of interaction local or global

- What are the institutions, organisations, legislation or associations that organise the functioning of a market, as well as their responsibilities and enforcement tools to 'make the market work'?

- How is price determined? Are prices set outside or in the market? If it is a price-setting market, does this lead to different bilateral prices?

- What is the form of competition in each market in light of the number of traders, distribution of ownership and market power?

- What information is available to whom? Where is it available? What skills are needed to access or process market information?

- What is the role of the state? 
Set out below is a broad overview of the development and operation of each market selected for analysis. This description is not definitive but establishes the context for the subsequent detailed comparison of the five markets' structural features, interactions and outcomes. The descriptions and comparison seek to answer each of the above questions with respect to each market analysed.

\subsection{Electricity}

The Australian electricity sector of the early 1990 s is unrecognisable today. Former government businesses have been broken up into multiple single function companies, with the functions of generation and retail exposed to competition and the natural monopoly functions of transmission and distribution regulated to support competition. Some of these companies have been privatised. The majority of consumers can choose their electricity supplier following the progressive introduction of retail competition. A wholesale National Electricity Market (NEM) has been created through which the vast majority of electricity generated and consumed in Australia is traded. ${ }^{1}$ A parallel electricity derivatives market also has been created to manage wholesale price risk. Regulation of transmission and distribution has been transferred from State governments to Federal regulators. A core feature of the electricity sector's restructuring has been to place far greater reliance on the market to determine pricing and investment outcomes.

Thirty-four government electricity companies existed in 1990. By November 2009, the NEM had 139 registered participants compared to 77 when the market commenced in late 1998 (AEMO 2009b; NEMMCO 1999). Across the NEM, private ownership accounts for around 30 per cent of generation and transmission capacities respectively, 52 per cent of services to distribution customers and more than 60 per cent of services to retail customers (Chester, 2007). Offshore transnationals dominate private ownership.

The Australian Energy Market Commission and the Australian Energy Regulator are responsible for the oversight and regulation of the NEM. The National Electricity Rules (Rules) prescribe the NEM's day-to-day operation. The Rules prescribe six types of market participant (e.g. generator, customer, network service provider, trader), the process to achieve registered participant status and the terms under which each will engage in the market. All market participants must comply with a prescribed prudential framework administered by the Australian Energy Market Operator (AEM). The "stability and financial integrity of the NEM is underpinned" (NEMMCO 2003: 12) by this framework and, in conjunction with derivatives, ensures the "efficient management of financial risk for parties trading in the NEM" (ibid: 3 ).

The Rules are structured around a mandatory requirement that each generator, with a capacity greater than 30 Megawatts (MW), must sell all electricity produced through the NEM. The Rules also require the market and system operator - the Australian Energy Market Operator (AEMO) - to monitor demand, forecast supply capacity and operate a centralised process whereby generating units are scheduled and dispatched into production to ensure instantaneous matching of supply and demand. The dispatch process is driven by generators' bids to produce a volume at particular prices. Bids are 'stacked' in order of ascending price as

\footnotetext{
${ }^{1}$ The NEM covers southern and eastern Australia (Queensland, NSW, ACT, Victoria, Tasmania and South Australia). The geographic remoteness of the population centres of WA and the NT make the cost of transmission interconnection to a national grid prohibitive. Restructuring of the WA electricity sector has essentially mirrored that involving the NEM.
}

Society of Heterodox Economists, December 2009 
the AEMO matches the generating capacity declared available against forecast demand. As demand increases, the more costly bids are scheduled into production.

The Rules also set out the process to determine the wholesale price. First, the price for each five minute dispatch interval is derived. This is usually the highest bid generator brought into production to meet demand. Second, a time-weighted average is calculated of the six dispatch prices for each half hour trading interval for each NEM region. There is no single NEM wholesale price. The Rules also specify the maximum price which generators may bid. ${ }^{2}$

The level of wholesale prices - particularly, its volatility or spikes - is claimed to signal the need for investment in additional generation capacity (COAG Energy Market Review 2002; NSW Government 2004). "As the capacity of available generation to meet demand diminishes, relative scarcity will lead to an increase in the spot price, and new generation or network capacity will be attracted into the market" (AEMO 2009: 7). Price volatility within the NEM has been widely acknowledged but spikes have regularly occurred at levels well below maximum demand and have not stimulated investment in baseload capacity (Chester 2008a). The increase in NEM generating capacity has been dominated by peaking capacity with marginal additions to baseload through augmentation of existing plant. Moreover, uncertainty about carbon trading (which we discuss shortly), and climate change policies more generally, has been cited as a serious impediment to generation investment (Productivity Commission 2005). Consequently the adequacy of Australia's capacity to meet forecast long-term demand for electricity is under threat (Chester 2008c).

Retail (end-use) prices for households have shown significant increases. Contrary to the policy rhetoric, the vast majority of Australian households have not changed electricity supplier and the price of their electricity is set by regulation. The charges comprising regulated household electricity prices are set by a combination of Federal and State-by-State regulation. Not only is the charge-setting process complex, multiple tariffs contribute to each of the basic charges and these can vary considerably between urban, regional and rural locations as well as States and Territories. Periodic review of these charges has led to significant price increases in all States and Territories. All Australian governments have agreed to phase out this form of price regulation subject to evidence of effective competition (Victoria led the way from 1 January 2009) which means that electricity suppliers will set the end-use prices paid by households (Chester 2007; COAG 2006).

Market power and ownership concentration are also present in the NEM. The National Electricity Rules permit re-bidding by generators which has resulted in the generators wielding considerable market power (Chester 2006, 2007, 2008a). Although the number of sellers (generators) has increased considerably, a small number of companies dominate generation capacity in each NEM region. Three private companies hold ownership interests for around 80 per cent of Victorian capacity and two of these owners dominate South Australian generation capacity. Government ownership accounts for at least two-thirds of total NEM generation capacity (Chester 2006, 2008a). Two strong trends driving a more concentrated market structure have been consolidation within the retail sub-sector and re-integration of generation with retail activities (Chester 2007).

\footnotetext{
${ }^{2}$ At the commencement of the NEM in late 1998, the maximum wholesale price was set at $A \$ 5000$ per MWh, increased to its current level of $A \$ 10,000$ per MWh in April 2002 and will increase to $\$ 12,500$ per MWh from June 2010.
} 


\subsection{Water}

Traditionally water and wastewater services have been provided by government-owned monopoly providers managing all aspects of the water supply chain from dams to taps, and from sewers to treatment plants and disposal. These services currently operate under a mix of industry structures including: vertically-integrated government-owned suppliers for an entire State or region (e.g. South Australia and Western Australia); separation of the bulk harvesting and supply functions from distribution and retail (e.g. Sydney and Melbourne); and, urban water provision by local government (e.g. Queensland, Tasmania and regional NSW) (Frontier Economics 2008).

This range of industry arrangements is marked by four aspects. First, government authorities predominate with private sector involvement skewed towards capital construction (and possibly operation and maintenance, through public-private partnerships (PPPs)) and the provision of inputs through competitive procurement practices by government providers. Second, there is very little direct competition in the supply of water and wastewater services with customers being supplied by a monopoly provider. Third, market-based mechanisms have been progressively - but not universally - implemented across this sector e.g. full cost recovery pricing, separation of policy and regulatory functions from actual service delivery, licensing of providers. Fourth, water trading arrangements have become increasingly prevalent in the Australian rural water market (Australian Government 2006; ibid).

A market for Australian water trading was initiated with the 1994 Council of Australian Governments (COAG) decision to implement a system of water allocations or entitlements supported by the separation of water property rights from land title, and specification of entitlements in terms of ownership, volume, reliability, transferability and quality (COAG 1994). The same meeting also agreed for water pricing to be based on usage charges, full-cost recovery, the reduction or elimination of cross-subsidies, and the adoption of an access or connection charge - in addition to usage charges - for all urban water users.

These decisions, taken in the context of COAG's agreement to the National Competition Policy from the mid 1990s, also saw commitments to separate water resource management policy responsibility, standard setting, regulatory enforcement and service provision from those agencies which actually delivered and sold water. This led to the corporatisation of government-owned water utilities and a more commercial focus across the water sector (Australian Government 2006).

Two kinds of water trading markets have developed in Australia - temporary (i.e. seasonal water allocations) and permanent (i.e. access entitlements). Market participants exchange their allocations or entitlements i.e. there is an exchange of water rights at an agreed 'market-clearing' price (Silby 2008). The use of the temporary (allocation) market has been the most significant in Australia to date facilitated by the emergence of water exchanges particularly in Victoria and NSW (Bjornlund 2004). Temporary trades between individual water users when water availability is low have accounted for the major part of activity, especially in the southern Murray-Darling Basin (ACIL Tasman 2003; Crase, O'Keefe et al 2008).

In Australia, the overarching right to the flow, use and control of water is vested in the States. Water is defined in State-based legislation generally as that found in naturally occurring watercourses and aquifers. Each State jurisdiction has its own water management planning processes and policies, as well as the means to confer rights to water to other parties and the environment. In addition, there have been a range of decisions by the COAG about water resource management. Consequently water market transactions are governed by policy, 
legislative and institutional frameworks at the national, state and local levels which encompass the types of transactions permitted, the products to be traded, and trading rules (ibid).

Water trading is important because it allows scarce water resources to be transferred to their most productive uses ... Creating an environment in which individual water access entitlement holders are able to trade water quickly and easily will contribute to a more productive and efficient use of Australia's water over time (National Water Commission 2009).

These notions underpin the development of Australian water trading and the successive decisions of the COAG to develop Australia's water markets. However, as prolonged drought has exacerbated water supplies, the ability of rural and urban water markets to meet these objectives is being thwarted. As a result, the COAG has agreed new arrangements for the Murray-Darling Basin, the producer of one third of Australia's food supply, including Federal Government buyback of water entitlements and new regulatory arrangements (COAG 2008). In urban water markets, supply shortages have led to significant, long-term restrictions on use, subsidies for 'water-efficient' appliances and installation of rainwater tanks, extensive government information campaigns, and the increased application of 'scarcity' pricing. Governments around Australia have also embarked on the construction, through PPPs, of energy-intensive desalination plants to augment supply.

But these measures overshadow the features sharply delineating Australia's contemporary urban and rural water markets - increasing access and usage charges for urban users; a myriad of complex regulatory and licensing arrangements; uncertainty amongst participants about future supply; poorly defined, and jurisdictionally inconsistent, property rights to access and entitlement; and increasingly direct intervention by the Federal Government (ACIL Tasman 2003; Bjornlund 2004; National Water Commission 2008).

\subsection{Employment services for the unemployed}

The genesis of a competitive market for employment services to the unemployed was the Federal Labor Government's 1994 Working Nation, a package of policies to promote economic growth and employment (Australian Government 1994). These policies included individualised case management for the long-term or disadvantaged unemployed "to identify the most suitable path to augment a client's employability" (O'Neill 1999: 8). A competitive tender for contracted case management, on a fixed-price basis, resulted in the single public sector provider, the Commonwealth Employment Service (CES), competing to deliver this service with a range of private and not-for-profit providers. In addition, the CES contracted a range of agencies to provide, for a fee, job or training experience for the unemployed.

This progressive shift towards private sector provision of services to the unemployed accelerated in 1998 when the CES - which had existed since 1946 - was effectively abolished to be replaced by a national network of employment service providers. The Federal Government became a "purchaser of employment services" (ibid). Contracts established a schedule of fees for job matching, job search training and intensive assistance services.

Job Network, as this provision of services to the unemployed was labelled, created a national network of organisations (private, community and some formerly, government) contracted by the Federal Government through a competitive tender process. ${ }^{3}$ Initial contracts (1998-2000, 2000-03) were awarded on the basis of price and quality. Later contracts

\footnotetext{
${ }^{3}$ For the purposes of the tender, Australia is divided into labour market regions and providers are requested to tender for the required services specified for each region.
}

Society of Heterodox Economists, December 2009 
(2003-08) were awarded on the basis of 'quality', a performance rating model assessed by the Federal Government, with fixed floor prices for each service (Thomas 2007). Eardley (2003: 32) observed that, with the third round of contracts, the Job Network had become a

concentration of the key employment services, both in terms of the number of agencies and the number of sites ... Public sector involvement is reduced to a few local or State government projects, while the private agencies and non-profit sector have consolidated their roughly equal market share.

In 2009, Job Network morphed into Job Services Australia which is in essence the same network of contracted employment services to be provided by the private and not-for-profit sectors. However, all those unemployed - not just the long-term unemployed or most disadvantaged jobseekers - are eligible to access these services and two overseas providers, of 114 in total, are now part of the network to deliver employment services (O'Connor 2009).

This reconfiguration of employment services provision, under the guise of competition, efficiency, rewards for outcomes and 'some' consumer choice (Productivity Commission 2002), has been described as a 'managed' or 'quasi' market, akin to that defined by Le Grand and Bartlett (1993). Previously this market had a single public sector supplier, the CES. Now the Federal Government purchases, by contract, the specified employment services from multiple non-government suppliers - one buyer, multiple sellers. The Federal Government also regulates this market through contract performance review.

The Federal Government, as sole buyer, purchases on behalf of multiple recipients of these services - the unemployed - but mandates certain behaviours as criteria to access these services. Those receiving unemployment benefits are eligible to access employment services. ${ }^{4}$ To continue receiving unemployment benefits, there are mandatory activity test or participation requirements including attendance at all job interviews, acceptance of 'suitable' job offers, evidence of searching for 'suitable paid work', and not exiting training or a job without valid reason (Centrelink 2009). Ongoing compliance with these requirements is a condition of payment. Once registered for unemployment benefits, you are then permitted to register online with an employment services provider. A considerable amount of the unemployed's interaction with Centrelink - the public sector organisation responsible for the delivery of welfare payments - and employment service providers is via the internet. Apart from the need for computer access, this interaction requires levels of literacy, numeracy and computer skills so that the unemployed can 'navigate' their way through this market, make informed choices about service providers, search for work, and comply with mandatory reporting requirements.

Outcomes of this market have been found to be 'creaming' and 'parking' of job seekers arising from a performance-linked payment structure. Those requiring more intensive assistance are 'parked' while those job seekers with greater changes of achieving payable outcomes are targeted or 'creamed' (Cowling and Mitchell 2002; Productivity Commission 2002). The market has also been found to be less costly than its predecessor with a range of innovations in service delivery but "agencies (are) vulnerable to acceptance of downward pressure from employers on the quality and conditions of work offered, and makes it hard to resist some employers' discriminatory practices" (Eardley, Abello et al 2001: 62). Those with minimal barriers to employment need little or no assistance from this market because they find work readily but there have far more limited outcomes for the longer term and more

\footnotetext{
${ }^{4}$ Not all those unemployed receive unemployment benefits. The income support payments which fall within the category of unemployment benefits are Newstart Allowance, Youth Allowance, Parenting Payment and Special Benefit which have participation or activity test requirements.
} 
difficult-to-place job seekers particularly as substantial administrative and compliance demands have been imposed upon contracted providers (Thomas 2007).

\subsection{Housing for low-income Australians}

Housing for 19 per cent of Australian households is provided by the private rental market and a further five per cent rely on public and community housing (Productivity Commission 2009: 16A.72). Housing stress, where 30 per cent or more of gross income is committed to housing costs, is severest for renting households. Yates (2008) estimates that the incidence of housing stress had risen to 65 per cent for lower income private renters in 2002-03. ${ }^{5}$ It has also been found that the persistence of housing stress is highest amongst this group (Marks and Sedgwick 2008). The private and public markets for low-cost rental housing, since the mid 1990s, have been significantly impacted by demand-side and supply-side measures provided by government.

In 1945 the Commonwealth-State Housing Agreement (CSHA) was conceived to construct new rental dwellings to deal with the post war housing shortage. The 1973 CSHA introduced targeting of assistance to low income earners which accelerated from the mid 1990s. The 1996 CSHA emphasised housing outcomes for individuals rather than increasing stock, tighter targeting of stock allocation (to those on the lowest incomes) and removed any requirement for funds to be used to create new stock. Subsequent CSHAs reinforced this direction (McIntosh 1997, 2000; McIntosh and Phillips 2001). ${ }^{6}$ The total stock of public and community housing has declined since the mid 1990s coinciding with tighter targeting to those in greatest need, a real terms decline in Federal funding of 24 per cent from 1998-99 to 2007-08, and greater reliance being placed on the private rental market (Productivity Commission 2009).

Eligibility criteria for access to public housing varies across each State and Territory jurisdiction in terms of income and asset limits, residency requirements, waiting list segmentation (and lengthening), periodic reviews of eligibility and rent rebates (ibid: 16.6). All housing authorities apply rent affordability benchmarks of around 25 per cent of assessable income i.e. a rebate on market rent. In 2007-08, 88 per cent of public housing tenants paid less than market rent (ibid: 16A.1).

Rent assistance, a 'demand-side' form of housing assistance, is provided by the Federal Government to those renting in the private housing market and who receive income support payments, or those not receiving income support but who receive the base level of designated family payments (DFHCSIA 2009a). Rent assistance, indexed twice yearly by the CPI, is paid according to minimum thresholds and maximum rates which vary according to household type and number of dependents. There is no affordability benchmark like for public housing tenants and no differentiation between rural and urban rental markets. Without rent assistance, it has been estimated that nearly 27 per cent of recipients in 2008 would have spent more than 50 per cent of their gross income on rent (Productivity Commission 2009: 16.82).

\footnotetext{
${ }^{5}$ Marks and Segdwick (2008) estimated 40 per cent of households in the lowest quartile of equivalised disposable income were in housing stress in 2006. Yates' estimate is for the lowest 2 quintiles of equivalised disposable household income.

${ }^{6}$ Traditionally the Federal Government provided about two-thirds of total CSHA funding with the remainder from the States and Territories. About three-quarters of Federal funds was for public housing with the remainder to aboriginal rental housing, crisis accommodation and community housing.
}

Society of Heterodox Economists, December 2009 
In 2007-08 expenditure on rent assistance reached $\$ 2.3$ billion for nearly 950,000 recipients (compared to $\$ 1.3$ billion by all Australian governments for around 377,000 public and community housing tenants). Expenditure on rent assistance has escalated while funding of public housing has fallen (Productivity Commission 2009). This significant shift away from supply-side to demand-side measures is predicated on three notions: that low income is the primary reason for housing (un)affordability; that increased income will mean greater private rental choices for low-income households; and the private rental market will supply affordable and appropriate housing at the price demanded by low-income households. However, the private rental housing market has 'failed' given the ongoing shortage of low cost private rental dwellings (Berry 2003; Yates and Wulff 2000, 2005).

Since mid 2008, the Federal Government has announced three measures intended to stimulate the supply of low-cost rental housing:

- the National Affordable Housing Agreement, a 'rebadged' CSHA, continues the established base funding for public housing and indigenous, community and crisis housing with marginal increases in funding;

- the National Rental Affordability Scheme, directed at large-scale development, is intended to supply 50,000 low-cost rental dwellings by 2012. Financial incentives are provided, to eligible investors, for 10 years subject to the dwellings being rented at 20 per cent below market rate to tenants whose eligibility is assessed against an income cap; ${ }^{7}$ and

- the Social Housing Initiative, announced as part of the Federal Government's 'Nation Building - Economic Stimulus Plan', is intended to increase, by mid 2012, the stock of social housing dwellings by 20,000 and refurbish 47,000 existing public and community housing dwellings (DFHCSIA 2009c).

These additions to the low-cost rental housing market will take some time to materialise but, if successful, represent barely a third of that required for the 215,000 applicants on the waiting list for public and community housing at 30 June 2008 (Productivity Commission 2009).

\subsection{Carbon trading}

The Federal Government's Carbon Pollution Reduction Scheme (CPRS) is an exemplar with few parallels or precedents of a market-based policy solution which impacts on each and every Australian. The scheme is scheduled to start from 1 July 2011. It is a cap-and-trade scheme whereby the Government will set an annual limit (cap) on the total amount of carbon emissions permitted. Annual scheme caps will be announced five years in advance. Permits, that represent a right to emit a specific amount of carbon, will be issued by the Government and traded at auction. The total amount of emissions covered by the permits issued will equal the government-set cap.

Details of the scheme were released in late 2008 (Australian Government 2008a) with amendments, particularly to transitional arrangements, subsequently announced following heavy lobbying by business and negotiations between the major political parties. The CPRS will cover stationary energy (including electricity generation), transport, industrial processes,

\footnotetext{
${ }^{7}$ The Federal Government provides $\$ 6000$ per dwelling per year as a refundable tax offset or payment. State and Territory governments provide $\$ 2000$ per dwelling per year as a payment or in-kind financial support. Applicants must meet criteria such as demonstrated capacity, financially viable proposal and demonstrated need for the proposal (DFHCSIA 2009b).
}

Society of Heterodox Economists, December 2009 
waste, and fugitive emissions from oil and gas. The emissions from these activities represent about 75 per cent of Australia's total emissions and involve around 1000 entities.

Entities within Australia that emit carbon to do business will be required to buy permits (or may be allocated free permits). Monthly auctions of permits, for the current year and up to three years in advance, will be held. An ascending clock auction is proposed whereby the price will rise until the number of units demanded by bidders matches the number for sale. ${ }^{8}$ However, the Federal Government has announced that a fixed price of $\$ 10$ per tonne of $\mathrm{CO} 2$ will apply for the first year of the scheme.

One permit will provide an entity with the right to emit one tonne of $\mathrm{CO} 2$ or its equivalent. The newly created Australian Climate Change Regulatory Authority (ACCRA) will conduct the permit auctions and determine the eligibility of businesses to buy permits based on emissions data provided under the mandatory National Greenhouse and Energy Reporting (NGER). Reporting under the NGER is triggered if a business or facility surpasses the minimumspecified thresholds for the production of direct greenhouse gas emissions, energy production or energy consumption. Criminal and civil penalties are proposed for non-compliance and large emitters will be regularly audited by ACCRA.

Businesses will be required to surrender a permit (irrespective of whether bought at auction or administratively allocated) to ACCRA, at the end of each compliance period, for every tonne of emissions which they produce. Businesses can trade permits between themselves, can 'bank' them and some borrowing of future permits will be allowed. In addition, the market will allow permits to be bought and sold internationally.

The key transition measures, to apply for at least the first ten years of the CPRS, are:

- Assistance to 'emissions-intensive-trade-exposed' (EITE), to avoid 'loss of competitiveness, in the form of free permits. ${ }^{9}$ ACCRA will assess if activity meets EITE eligibility criteria and the rate of assistance (most exposed activities will get up to 95 per cent of permits free). This assistance will be reviewed every five years with a five-year notice period of changes;

- Assistance to coal-fired electricity generation which provides around 75 per cent of domestic electricity production and contributes some 35 per cent to Australia's emissions. Free permits will be provided to generators for ten years subject to capacity being maintained and a 'windfall gain' review; and

- Compensation to households for higher energy prices will be provided through an increase in payments for those receiving income support payments and Family Tax Benefit. In addition the excise tax on fuel will be reduced by one cent for every commensurate rise due to pass through of the cost of carbon trading.

This broad-brush sketch of the CPRS, and its key transition measures, illustrates this new market's complexity underpinned by a very substantive administrative, legislative and regulatory regime. Considerable doubt has been cast on the scheme's efficacy to reduce emissions given the government's forecasts assume no change to the contribution of coal-fired capacity to electricity generation before 2033 (Australian Government 2008b: 33). Other expected outcomes are: household energy expenditure to rise, on average, from $\$ 6-7$ or up to $\$ 12$ per week (Australian Government 2008b, 2009c); a direct budgetary cost of more than $\$ 8$ billion over 10 years (Australian Government 2009a, 2009b); TNC owners of EITE activities and

\footnotetext{
${ }^{8}$ Auction rules, procedures and payment arrangements are still being designed.

${ }^{9}$ Examples of EITE activities expected to receive assistance are aluminium smelting, integrated iron and steel manufacturing, petroleum refining and LNG production.
}

Society of Heterodox Economists, December 2009 
coal-fired electricity generators to gain considerably given current ownership patterns (Innovest 2008); and, the potential for large price swings (Metcalfe 2009: 15). These sort of prospective outcomes reinforce the "messy, highly politicised material reality of such markets" (MacKenzie 2007: 17).

Box 3 compares the key structural features, interactions and outcomes of the five markets described above from which we reach some conclusions about actually existing markets via-à-vis the abstract notion of markets provided by mainstream neoclassical economics which has smothered Australian public policy.

\section{$4 \quad$ Implications of market-based public policies}

Markets are not purely about relationships between inanimate objects, between goods and services, which is the strong impression evoked by any mainstream economics text or government publication. Markets involve people, their preferences (which cannot be isolated from opinions, values and the influence of advertising) and relationships with others. Market prices also will influence people's accessibility to, and participation in, a market. Markets, shaped by public policies, determine - to a significant measure - the health, standard of living and social inclusion of the population.

The preceding analysis and comparison of five contemporary Australian markets allows a number of conclusions to be readily drawn.

First, eligibility to participate in a market, by both buyers and sellers, requires predetermined criteria - usually set by regulators - to be met. These criteria are not static, can be quite complex and may involve a cost or 'entry fee' (e.g. water connection fee), assessment by a regulator (e.g. competitive tender, data provided by participant) or eligibility to be established first by another market (e.g. welfare recipients). Payment of the price of a good or service, traded in a market, does not determine eligibility to be a market participant.

Second, ongoing market participation is not assured even if eligibility criteria are satisfied. Participants may be required to make a regular payment (e.g. annual NEM fees), be limited to a fixed term by contract, be subject to regular re-assessment of eligibility, or make payment for goods and services by supplier-determined time and method. Payment of the price of a good or service is insufficient for buyers to maintain ongoing market access.

Third, government policy measures directly impact on the demand and supply of the goods and services sold in each of the markets analysed and hence, the interventions of government are directly determining market outcomes not relative prices.

Fourth, regulators actively determine prices in each of the five markets analysed. Price is not being determined by the 'forces of supply and demand'. The water trading market was the only market found to have price agreed by buyer and seller but heavily determined by the extent to which property rights are specified.

Fifth, intermediaries are evident in many markets, most commonly as market operators. 
Box 3: Comparison of the structural features, interactions and outcomes of five Australian markets

\begin{tabular}{|c|c|c|c|c|c|}
\hline & Electricity & Water & $\begin{array}{l}\text { Employment services } \\
\text { for the unemployed }\end{array}$ & $\begin{array}{l}\text { Housing for the low- } \\
\text { income }\end{array}$ & Carbon trading \\
\hline What is the commodity? & Electricity supply & Water supply & $\begin{array}{l}\text { Job referral, job search } \\
\text { training, training/work } \\
\text { experience, individual } \\
\text { case management }\end{array}$ & $\begin{array}{l}\text { Low-cost housing in } \\
\text { private and public } \\
\text { markets }\end{array}$ & Permit to pollute \\
\hline $\begin{array}{l}\text { What is the ownership } \\
\text { pattern? }\end{array}$ & Mixed & Public & Private & Mixed & Public \\
\hline $\begin{array}{l}\text { Who are eligible buyers } \\
\text { (end-users)? }\end{array}$ & $\begin{array}{lr}\text { All organisations, } \\
\text { companies, } \\
\text { households } \\
\text { to the grid }\end{array}$ & $\begin{array}{l}\text { All organisations, } \\
\text { companies and } \\
\text { households connected to } \\
\text { water supply system }\end{array}$ & $\begin{array}{l}\text { Federal Government on } \\
\text { behalf of those receiving } \\
\text { unemployment benefits }\end{array}$ & $\begin{array}{l}\text { Those receiving income } \\
\text { support payments and } \\
\text { base level family } \\
\text { assistance }\end{array}$ & $\begin{array}{l}1000 \text { entities assessed to } \\
\text { be largest emitters }\end{array}$ \\
\hline $\begin{array}{l}\text { How do buyers (end- } \\
\text { users) maintain market } \\
\text { access? }\end{array}$ & $\begin{array}{l}\text { Pay connection fee plus } \\
\text { access and usage } \\
\text { charges by supplier- } \\
\text { determined time and } \\
\text { method }\end{array}$ & $\begin{array}{l}\text { Pay usage and access } \\
\text { charges by supplier- } \\
\text { determined time and } \\
\text { method. Pay agreed } \\
\text { price for exchange of } \\
\text { water rights }\end{array}$ & $\begin{array}{l}\text { Retain eligibility for } \\
\text { unemployment benefits, } \\
\text { meet reporting } \\
\text { obligations and register } \\
\text { with Job Services } \\
\text { Australia }\end{array}$ & $\begin{array}{l}\text { Retain eligibility for } \\
\text { income support, and } \\
\text { base level family } \\
\text { assistance. Meet } \\
\text { thresholds for rent } \\
\text { assistance and eligibility } \\
\text { for public housing }\end{array}$ & $\begin{array}{l}\text { Eligible to buy permits } \\
\text { based on annual } \\
\text { regulator assessment of } \\
\text { emissions from company } \\
\text { supplied data }\end{array}$ \\
\hline $\begin{array}{l}\text { Who are the eligible } \\
\text { sellers and how do they } \\
\text { maintain market access? }\end{array}$ & $\begin{array}{l}\text { NEM participants must } \\
\text { register, meet/maintain } \\
\text { strict prudential criteria } \\
\text { and pay annual fees. } \\
\text { Retail companies must } \\
\text { be licenced by State } \\
\text { government regulators } \\
\text { to operate in respective }\end{array}$ & $\begin{array}{l}\text { State and local } \\
\text { government authorities. } \\
\text { Sellers of water } \\
\text { entitlements } \\
\text { allocations }\end{array}$ & $\begin{array}{l}\text { Providers contracted for } \\
\text { fixed 3-year term }\end{array}$ & $\begin{array}{l}\text { State government } \\
\text { authorities } \\
\text { public housing stock. } \\
\text { Federal Government } \\
\text { provides rent assistance } \\
\text { payments and incentives } \\
\text { to stimulate construction } \\
\text { of new rental stock. }\end{array}$ & $\begin{array}{l}\text { Government will auction } \\
\text { permits }\end{array}$ \\
\hline
\end{tabular}

\footnotetext{
${ }^{10}$ Although there is marginal difference with Job Network, the arrangements described reflect those as at 2009 following the introduction of Job Services Australia.
}

Society of Heterodox Economists, December 2009 
Box 3: Comparison of the structural features, interactions and outcomes of five Australian markets

\begin{tabular}{|c|c|c|c|}
\hline ( & Electricity & Water & $\begin{array}{l}\text { Employment services } \\
\text { for the unemployed }{ }^{10}\end{array}$ \\
\hline
\end{tabular}

jurisdictions.

$\begin{array}{lrlrl}\begin{array}{l}\text { Demand-side } \\ \text { provided }\end{array} & \text { measures } & \text { NEM allows for } & \text { Restrictions on use } \\ \text { government? } & \text { by } & \text { withdrawal or 'load enforced, in part, by } \\ & \text { shifting' by large market financial } & \text { penalties. } \\ & \text { customers } & \text { when } & \text { Water } & \text { efficiency } \\ & \text { wholesale price passes a information campaigns. } \\ & \text { threshold e.g. aluminium } & \text { Subsidies to install } \\ \text { smelters } & \text { water-efficient } \\ & & \text { appliances. Application } \\ & & \text { of 'scarcity' pricing }\end{array}$

Supply-side measures Limited augmentation of Construction

provided

government?

by govt-owned generation desalination

capacity. 10-year Limited measures to

of generation and Trading of entitlements

transmission capacity to and allocations

meet forecast demand

How is
determined? price Half-hourly wholesale price set by marke operator but capped at $\$ 10,000$ per MWh Transmission

distribution: regulated

Retail: regulated for

majority of households

\section{Housing for the low- Carbon trading}

\section{income}

Private sector must meet

criteria for financial

incentives. of

plants.

Rent assistance for those in private rental market. Rent rebate for those in public housing.

Competitive tender to
provide services for a contracted period

Provision

of

public

housing stock. Funding of community housing.

Tax rebates/subsidies to

private sector to

construct new rental

dwellings for low-income

Rate of rent assistance Urban: State regulators Performance-linked set access and usage charges in respective jurisdiction.

payments set

by

Government as part of ann competitive tender.

annual Federal budget

process. Rent rebate subject to National Affordable Housing Agreement. Other supply-side measures then floating price.
Transitional assistance for coal-fired electricity generation (free permit allocation) and EITE industries (partial free permit allocation) for at least 5 years. Tax deductibility of permits.

Government sets up and maintains permit auction

1st year fixed price of $\$ 10$ per tonne of $\mathrm{CO} 2$ (set by government)

Society of Heterodox Economists, December 2009 
Box 3: Comparison of the structural features, interactions and outcomes of five Australian markets

\begin{tabular}{|c|c|c|c|c|c|}
\hline & Electricity & Water & $\begin{array}{l}\text { Employment services } \\
\text { for the unemployed }{ }^{10}\end{array}$ & $\begin{array}{l}\text { Housing for the low- } \\
\text { income }\end{array}$ & Carbon trading \\
\hline & $\begin{array}{l}\text { until evidence of } \\
\text { 'effective competition' }\end{array}$ & & & $\begin{array}{l}\text { determined within } \\
\text { Federal budget process. }\end{array}$ & \\
\hline $\begin{array}{l}\text { Does buyer (end-user) } \\
\text { pay price? }\end{array}$ & $\begin{array}{l}\text { Yes. NEM customer pays } \\
\text { price set by market } \\
\text { operator. End-user pays } \\
\text { price charged by retailer }\end{array}$ & $\begin{array}{l}\text { Yes. End-user pays price } \\
\text { charged by supplier or } \\
\text { established through } \\
\text { trading }\end{array}$ & $\begin{array}{l}\text { Price paid by Federal } \\
\text { Government on behalf of } \\
\text { end-users, } \\
\text { unemployed }\end{array}$ & $\begin{array}{l}\text { No. Federal Government } \\
\text { sets and pay all 'prices' } \\
\text { of rent assistance, public } \\
\text { housing stock and } \\
\text { subsidies to private } \\
\text { sector }\end{array}$ & $\begin{array}{l}\text { Yes. Permit buyer pays } \\
1^{\text {st }} \text { year fixed price and } \\
\text { then auction price }\end{array}$ \\
\hline
\end{tabular}

How do buyers (end- NEM market operator Urban: Direct retailer- Online tender process. Online or direct interface Arrangements for clock users) and sellers acts as intermediary consumer interface via Unemployed persons with Centrelink, State auction envisaged to be interact? between generators and internet, billing or register online, meet housing authorities, online (like electricity retailer-consumer Trading: through water maintain contact via providers. housing trading). interface via internet, exchanges internet and in-person billing or phone. meetings.

What information is NEM market operator: Retailers: Consumer Details of tender and Eligibility rules for rent Expected to include provided to buyers (end- forecasts capacity and obligations and rights, outcomes. Locations of assistance and scale of forward calendar of users)? demand, NEM prices price, billing, payment providers and services. payments. Eligibility for auction dates, rules for Obligations and public/community auction dates, rules for
submitting/withdrawing obligations, price, billing Water brokers: price reporting requirements housing Application bids, number of permits payment terms determination, rules for if unemployed and Regulators: performance lodging offers, fees, penalties for breach reports of regulated trade eligibility, payment monopolies, outage terms.

investigations, price Regulators: performance determinations reports of regulated monopolies, rules for 
Box 3: Comparison of the structural features, interactions and outcomes of five Australian markets

$\begin{array}{cccc}\text { Electricity } & \text { Water } & \begin{array}{l}\text { Employment services Housing for the low- Carbon trading } \\ \text { for the unemployed }\end{array} \\ \text { income } & \text { water brokers, price }\end{array}$

determinations

\begin{tabular}{|c|c|c|}
\hline \multirow{3}{*}{$\begin{array}{l}\text { How is information } \\
\text { provided to buyers (end- } \\
\text { users)? }\end{array}$} & $\begin{array}{l}\text { Retailers: websites, } \\
\text { telephone, direct mail }\end{array}$ & $\begin{array}{l}\text { Retailers: websites, } \\
\text { telephone, direct mail }\end{array}$ \\
\hline & $\begin{array}{l}\text { National and State } \\
\text { Regulators: websites }\end{array}$ & $\begin{array}{l}\text { National and State } \\
\text { regulators: websites }\end{array}$ \\
\hline & & Water Brokers: websites \\
\hline \multirow{8}{*}{$\begin{array}{l}\text { What are the main } \\
\text { features of the } \\
\text { regulatory regime? }\end{array}$} & \multirow{3}{*}{$\begin{array}{l}\text { National Electricity Rules } \\
\text { (1251 pages). Australian } \\
\text { Energy Market Operator. }\end{array}$} & National \\
\hline & & Commission. \\
\hline & & Darling Basin Authority. \\
\hline & Australian & COAG Agreements. \\
\hline & Regulator. & \\
\hline & Energy & \\
\hline & Commission & \\
\hline & $\begin{array}{l}\text { States: Regulator } \\
\text { each jurisdiction }\end{array}$ & \\
\hline
\end{tabular}

What is the extent of the NEM: managed market market or form of Generation: oligopoly competition?

Transmission: monopoly in each State

Distribution: monopoly

franchise in each State

Retail: imperfect

competition

Urban:

franchise

monopoly

Rural: contested market

Contestable
market.

dominated by handful of

large private companies managed Providers

Government websites. Government website. Centrelink offices. Direct Centrelink offices. Direct mail to income support recipients

Federal Department of Centrelink. Federal 800-page White Paper. Workplace Housing, Community and explanatory Relations. Services and Indigenous memoranda. Australian Centerlink. Affairs. National Climate Change Affordable Housing Authority. Australian Agreement. National Carbon Trust. National Rental Affordability Greenhouse and Energy Scheme. Social Housing Reporting System. Initiative. Assessment rules for EITE assistance.

Managed market

Public rental: monopoly Private rental: contested

Society of Heterodox Economists, December 2009 
Box 3: Comparison of the structural features, interactions and outcomes of five Australian markets

\begin{tabular}{|c|c|c|c|c|c|}
\hline & Electricity & Water & $\begin{array}{l}\text { Employment services } \\
\text { for the unemployed }{ }^{10}\end{array}$ & $\begin{array}{l}\text { Housing for the low- } \\
\text { income }\end{array}$ & Carbon trading \\
\hline government & $\begin{array}{l}\text { regulator. Price regulator } \\
\text { for transmission, } \\
\text { distribution and retail. } \\
\text { Owner of substantial } \\
\text { generation, } \\
\text { transmission, } \\
\text { distribution and retail } \\
\text { capacity. }\end{array}$ & & contested market. & $\begin{array}{l}\text { housing stock. Regulator } \\
\text { of community housing. } \\
\text { Cash provision of rent } \\
\text { assistance. Funding of } \\
\text { new public housing } \\
\text { stock. Provision of tax } \\
\text { and financial incentives } \\
\text { to stimulate construction } \\
\text { of low-cost private rental } \\
\text { housing }\end{array}$ & $\begin{array}{l}\text { setter of } 1^{\text {st }} \text { year price. } \\
\text { Regulator (assessor of } \\
\text { permit eligibility and EITE } \\
\text { assistance; sets annual } \\
\text { cap). Buyer through } \\
\text { Australian Carbon Trust. }\end{array}$ \\
\hline $\begin{array}{l}\text { What are the key market } \\
\text { outcomes? }\end{array}$ & $\begin{array}{l}\text { Wholesale price volatility } \\
\text { not reflecting demand or } \\
\text { stimulating investment. } \\
\text { Electricity derivatives } \\
\text { market to manage } \\
\text { wholesale price risk. } \\
\text { Generators exercise } \\
\text { market power. Retail } \\
\text { consolidation. Retail and } \\
\text { generation re- } \\
\text { integrating. Significant } \\
\text { price increases for } \\
\text { households. Increasing } \\
\text { customer complaints and } \\
\text { disconnections. } \\
\text { Generation capacity } \\
\text { inadequate for forecast } \\
\text { long-term demand }\end{array}$ & $\begin{array}{l}\text { Inconsistent definitions } \\
\text { of property rights across } \\
\text { Australia. Markedly } \\
\text { higher charges paid by } \\
\text { all water consumers. } \\
\text { Desalination plants have } \\
\text { required purpose-built } \\
\text { energy capacity. Long- } \\
\text { term urban and rural } \\
\text { supply capacity is under } \\
\text { severe threat. Severe } \\
\text { deterioration of Murray- } \\
\text { Darling Basin }\end{array}$ & $\begin{array}{l}\text { Less costly than previous } \\
\text { sole provider provision. } \\
\text { High compliance and } \\
\text { administrative } \\
\text { requirements for } \\
\text { providers following } \\
\text { onerous/costly tender } \\
\text { process. Performance } \\
\text { based payments have } \\
\text { led to 'parking' and } \\
\text { 'creaming'. Limited } \\
\text { success for many long- } \\
\text { term or difficult-to-place } \\
\text { job seekers. High } \\
\text { reliance on unemployed } \\
\text { having internet access } \\
\text { and computer skills }\end{array}$ & $\begin{array}{l}\text { More than } 50 \% \text { of low- } \\
\text { income renting } \\
\text { households in housing } \\
\text { stress. Growing public } \\
\text { housing waiting lists. } \\
\text { Supply of public and } \\
\text { private rental stock not } \\
\text { responding to chronic } \\
\text { excess demand for cheap } \\
\text { rental housing. Stimulus } \\
\text { measures yet to } \\
\text { generate forecast stock } \\
\text { increases in low-cost } \\
\text { rental housing which } \\
\text { barely represent a third } \\
\text { of waiting lists for public } \\
\text { and community housing }\end{array}$ & $\begin{array}{l}\text { Complex scheme. Only } \\
75 \% \text { emissions covered. } \\
\text { Household energy costs } \\
\text { to rise by } \$ 6-7 / \text { week. } \\
\text { Compensation to income } \\
\text { support recipients, } 1 \\
\text { year after market start. } \\
\text { Reduction in fuel tax if } \\
\text { fuel price increases. } \\
\text { Coal-fired electricity } \\
\text { generation emissions } \\
\text { assumed not to fall } \\
\text { before } 2033 \text {. Budgetary } \\
\text { cost of \$4.8b. TNCs } \\
\text { benefit most from free } \\
\text { permit allocations and } \\
\text { EITE assistance. Potential } \\
\text { for large price swings }\end{array}$ \\
\hline
\end{tabular}

Society of Heterodox Economists, December 2009 
Sixth, the vast majority of interaction between market participants is via the internet requiring buyers to have computer access as well as literacy and numeracy skills. This may well pose barriers to full and ongoing participation.

Seventh, quite complex and detailed information is available to buyers relating to their participation, obligations, payments terms, penalties and performance data about providers. However, the ability to access, and skills to process, this information will determine the extent to which buyers use this information to make 'choices'.

Eighth, each market is underpinned by a very complex evolving legislative and regulatory regime involving multiple institutions.

Ninth, different types of market and extent of competition are evident such as contested, managed, monopoly franchise, and oligopoly. Imperfect competition was found only for the electricity retail market.

Tenth, government is a very dominant participant in all markets, performing multiple roles as regulator, owner of significant supplier assets, manager of stock, manager of contested markets, market operator, and buyer.

Eleventh, despite government demand-side and supply-side measures, and significant price increases in the majority of markets analysed, the key outcomes of each market show that supply is not meeting demand and one market (housing for low-income Australians) is evidence of chronic market failure.

Twelfth, market power and concentration are strongly present in the majority of markets analysed.

These conclusions confirm that the assumptions of the abstract market promulgated by neoclassical economics are incompatible with reality. Moreover, these conclusions provide strong affirmation the market is such a complex institution that it cannot be distilled or equated to the sum or aggregation of bilateral relationships which is the approach of neoclassical economics.

The analysis has also clearly shown, contrary to the view promulgated by mainstream economics imbued in public policy, there is not one but a spectrum of contemporary market configurations and exceedingly complex governance regimes in which government plays a multiplicity of direct interventionist roles in actual existing markets. Thus, the organisation of a capitalist economy, such as Australia, which attributes a leading role to competitive markets, can only be explained by ascertaining: the institutions, legislation, organisations, or interactions that organise the functioning of various markets; the series of commodities for which the supply and demand of is heavily determined by market institutions, including regulation by the state; and the forms of competition according to the number of traders, ownership distribution, market power, and the mechanisms to resolve capacity issues or structural changes (Boyer 1997: 70).

The analysis has also highlighted the critical role of technology to market participation, including the provision of buyer information, and the potential barriers posed by lack of computer literacy and numeracy skills. Market outcomes, in addition, were found to be inconsistent with policy rhetoric with the majority facing long-term capacity issues and one suffering chronic failure. A further important aspect strongly signalled by the results of the analysis is the interaction between markets and thus the strong potential for cumulative impacts. For example, the adequacy of electricity generation capacity is being threatened by 
the uncertainty about the operation of the carbon trading market which, when implemented, will lead to price increases in all other markets. These prospects provide a picture of some of the perils and pitfalls arising from $21^{\text {st }}$ century real world markets and pose potentially 'wicked problems' for policymakers.

Finally, the observed disjuncture between the institutional architecture of Australia's mode of régulation and neoliberalism's free market rhetoric was confirmed by the analysis to be replicated between the policy rhetoric and the structure, operation, interactions and outcomes of actually existing markets. But perhaps most importantly, this analysis of five contemporary Australian markets has starkly illustrated the market regime which is an inextricable part of Australia's current mode of régulation.

\section{References:}

ACIL Tasman (2003), Water trading in Australia: Current \& prospective products, Report prepared for the Water Reform Working Group, June

Amable, B. (2003), The diversity of modern capitalisms, Oxford: Oxford University Press

Australian Energy Market Operator (AEMO) (2009a), An introduction to Australia's national electricity market, July 2009, AEMO, Accessed 12 August 2009 from: http://www.aemo.com.au/corporate/publications.html

--- (2009b), Registration and exemptions lists - 28 October 2009, AEMO, Accessed 30 October 2009 from: http://www.aemo.com.au/registration/registration.html

Australian Government, (1994), Working nation: policies and programs, AGPS, Canberra, Statement presented by the Prime Minister, 4 May

--- (2006), A discussion paper on the role of the private sector in the supply of water and wastewater services, Department of the Prime Minister and Cabinet, Canberra, August

--- (2008a), Carbon Pollution Reduction Scheme: Australia's low pollution future, Volumes 1 and 2, White paper, Department of Climate Change, Canberra, December

--- (2008b), Australia's low pollution future: The economics of climate change mitigation, Summary, Treasury, Canberra, December

--- (2009a), Mid-year economic and fiscal outlook 2009-10, Treasury, Canberra, November

--- (2009b), 'Details of proposed CPRS changes', Statement accompanying Prime Minister's media release of 24 November, Department of Climate Change, Accessed 24 November 2009 from: http://www.climatechange.gov.au/en/media/whatsnew/ /media/publications/cprs/CPRS_ESAS/091124oppnofferpdf.ashx

--- (2009c), 'Household assistance under Carbon Pollution Reduction Scheme', Media release by Minister for Climate Change, Treasurer and Minister for Families, Housing, Community Services and Indigenous Affairs, 25 November. Accessed 25 November 2009 from: http://www.climatechange.gov.au/en/minister/wong/2009/mediareleases/November/mr20091125.aspx

Berry, M. (2003), 'Why is it important to boost the supply of affordable housing in Australia - and how can we do it?, Urban Policy and Research, 21(4): 413-35

Bjornlund, H. (2004), 'What impedes water markets?', Water, November, 48-54

Centrelink (2009), Activity test and participation requirements for job seekers, Australian Government. $\begin{array}{lllll}\text { Accessed } & 3 & \text { October } & 2009 & \text { from: }\end{array}$ http://www.centrelink.gov.au/internet/internet.nsf/filestores/lw054_0906/\$file/lw054_0906en.pd $f$

Chester, L. (2006), 'The conundrums facing Australia's national electricity market', Economic Papers, 25(4): 362-77

--- (2007), What are the outcomes and who benefits from the restructuring of the Australian electricity sector? Unpublished PhD thesis, University of New South Wales. Available at: http://www.library.unsw.edu.au/ thesis/adt-NUN/public/adt-NUN20071017.113919/ 
--- (2008a), 'The parlous investment environment for Australian electricity generation and transmission', IAEE Energy Forum, Second quarter, 29-35

--- (2008b), 'The contemporary growth regime has been ensured by the Australian state's mutations (at least until now), The Economic and Labour Relations Review, 19(1): 3-24

--- (2008c), 'The public policy labyrinth impacting on the security of Australia's energy supply: does it matter?, in Chester, L., Johnson, M. and Kriesler, P. (eds), Contemporary issues for heterodox economics, Refereed papers, Proceedings of the 7th Australian Society of Heterodox Economists Conference, 8-9 December 2008, University of New South Wales, Sydney, 31-53

--- (2009), 'How can we analyse real world markets', in Chester, L., Johnson, M. and Kreisler, P., Heterodox economics' visions, Refereed papers, Proceedings of the 9th Australian Society of Heterodox Economists Conference, 7-8 December 2009, University of New South Wales, Sydney

Council of Australian Governments (COAG) (1994), Communiqué, Canberra, 25 February

--- (2006), Communiqué, Canberra, 10 February

--- (2008), Communiqué, Adelaide, 26 March

Council of Australian Governments (COAG) Energy Market Review (2002), Towards a truly national and efficient market, AusInfo, Canberra, Final report (W. Parer, Chairman), 20 December

Cowling, S. and Mitchell, W. (2002), False promise or false premise? Evaluating the Job Network, Working Paper 02-12, Centre for Full Employment and Equity, University of Newcastle

Crase, L., O'Keefe, S. And Dollery, B. (2008), 'Can urban water markets work? Some concerns', Agenda, 15(3): 73-82

Crouch, C. (2005), Capitalist diversity and change: Recombinant governance and institutional entrepreneurs, Oxford: Oxford University Press

Department of Family, Housing, Community Services and Indigenous Affairs (DFHCSIA) (2009), Rent $\begin{array}{lllll}\text { assistance, } & \text { Accessed } & 6 & \text { October } & 2009\end{array}$ http://www.fahcsia.gov.au/sa/housing/payments/Pages/Rentassistance.aspx

--- (2009b), National Rental Affordability Scheme, Accessed 7 October 2009 from: http://www.fahcsia.gov.au/sa/housing/progserv/affordability/nras/Pages/default.aspx

--- (2009c), Social Housing Initiative, Accessed 7 October 2009 from: http://www.fahcsia.gov.au/SA/HOUSING/PROGSERV/SOCIAL_HOUSING/Pages/default.aspx

Eardley, T. (2003), 'Non-economic perspectives on the Job Network', Australian Journal of Labour Economics, 6(2): 317-29

Eardley, T., Abello, D. and Macdonald, H. (2001), Is the Job Network benefiting disadvantaged job seekers? Preliminary evidence from a study of non-profit employment services, SPRC Discussion Paper No. 111, Social Policy Research Centre/Brotherhood of St Laurence

Frontier Economics (2008), Urban water markets, A final report prepared for the Joint Steering Committee for Water Sensitive Cities, Melbourne, December

Hall, P. and Soskice, D. (eds.) (2001), Varieties of capitalism: the institutional foundations of comparative advantage, Oxford: Oxford University Press

Innovest (2008), Research Note: The impact of industry assistance measures under the Carbon Pollution Reduction Scheme, Prepared for the Australian Conservation Foundation, October

Le Grand, J. and Bartlett, W. (1993), 'Introduction', in Le Grand, J. and Bartlett, W. (eds), Quasi-markets and social policy, Houndsmill, Basingstoke: Macmillan Press, 1-12

MacKenzie, D. (2007), 'Finding the ratchet: The political economy of carbon trading', Postautistic Economics Review, 42: 8-17

Marks, G.N. and Sedgwick, S.T. (2008), 'Is there a housing crisis? The incidence and persistence of housing stress 2002-2006', Australian Economic Review, 41(2): 215-21

McIntosh, G. (1997), 'Reforming public housing', Current Issues Brief 31 1996-97, Parliamentary Library, Accessed 26 May 2009 from: http://www.aph.gov.au/library/pubs/CIB/1996-97/97cib31.htm

--- (2000), 'The changing face of public housing', Research Note 24 1999-00, Parliamentary

Library, Accessed 26 May 2009 from: http://www.aph.gov.au/library/intguide/sp/statehouseagree.htm

McIntosh, G. and Phillips, J. (2001), 'The Commonwealth-State Housing Agreement', Current

Issues E-Brief, Parliamentary Library, Accessed 26 May 2009 from:

http://www.aph.gov.au/library/pubs/rn/1999-2000/2000rn24.htm

Monro, D. (1998), 'Public rental housing policy: Learning the lessons from overseas', 
Metcalf, G. (2009), 'Market-based policy options to control U.S. greenhouse gas emissions', Journal of Economic Perspectives, 23(2): 5-27

National Electricity Market Management Company (NEMMCO) (1999), Annual report, Melbourne: NEMMCO

--- (2003), 'Financial risk management', NEMMCO, Accessed 15 May 2005 from: http://www.nemmco.com.au/publications/whitebook/financial.htm

National Water Commission (2008), Australian water markets report, National Water Commission, Canberra, December

--- (2009), National Water Initiative, Accessed 7 October 2009 from: http: www.nwc.gov.au/www/html/117-national-water-initiative.asp

Nelson, S. (ed) (2005), The limits of market organization, New York: Russell Sage Foundation

O'Connor, B. (2009), \$4 billion new employment services - Job Services Australia, Media release by the Federal Minister for Employment Participation

O'Neill, S. (1999), 'Changes to employment assistance: More of less effective', Research Paper 26 199899, Parliamentary Library, Accessed 21 September 2009 from: http://www.aph.gov.au/library/pubs/rp/1998-99/99rp26.htm (INTERNET)

Productivity Commission (2002), Independent review of the Job Network, Report No. 21, AusInfo, Canberra

--- (2005), Review of national competition policy reforms, Inquiry Report No. 33, Productivity Commission, Canberra

--- (2009), Report on government services 2009, Steering Committee for the Review of Government Service Provision, Productivity Commission, Canberra

Silby, H. (2008), 'Can urban water markets work? An optimistic view', Agenda, 15(3): 83-91

Thomas, M. (2007), A review of developments in the Job Network, Research paper 15 2007-08, Parliamentary Library

Yates, J. 'Australia's housing affordability crisis', Australian Economic Review, 41(2): 200-14

Yates, J. and Wulff, M. (2000), 'W(h)ither low cost private rental housing?', Urban Policy and Research, 18(1): 45-64

--- (2005), 'Market provision of affordable rental housing: Lessons from recent trends in Australia', Urban Policy and Research, 23(1): 5-19 